\title{
Performance of The Family Planning Population Control for Women's Empowerment and Child Protection Agencies in The Bkb-Hi Program in Murung Raya Regency
}

\author{
Sholihatul Amaliah*, Samahuddin, Jamaluddin
}

Master Program of Government Science, Lambung Mangkurat University, Banjarmasin, Indonesia

\author{
DOI: $10.36348 /$ SJNHC.2019.v02i10.002 \\ | Received: 26.09.2019 | Accepted: 03.10.2019 | Published: 15.10.2019 \\ *Corresponding author: Sholihatul Amaliah
}

\section{Abstract}

Services for early childhood in Murung Raya have been carried out by various programs, one of which is the Development of an Integrative Holistic Toddler Family (BKB-HI) by the Office of Population Control, Family Planning, Women's Empowerment and Child Protection (DP2KBP3A). However, the implementation of this program experienced several obstacles, namely the number of BKB-HI groups was still minimal, the implementation of programs in each group was not evenly distributed, the low quantity and quality of cadres, and the role of field officers was still not optimal. This study aims to determine the performance and factors that influence the performance of DP2KBP3A in Murung Raya Regency especially in the BKB-HI program. Performance measurement uses four performance measurement indicators, namely: productivity, responsiveness, responsibility, and accountability. This study uses a qualitative approach with case study design. Data collection techniques through interviews, observations involved and focus groups and then analyzed using a model developed by Miles \& Huberman, namely data reduction, data presentation and conclusion. The location of this study is in Murung Raya Regency. The results of the study concluded that: (1) The performance of DP2KBP3A can be seen through several indicators, namely: (a) productivity, in terms of effectiveness, has not been able to achieve effectiveness because it has not been able to give an impact according to the expected goals; (b) responsiveness, proposals and aspirations of the community have been followed up by accommodating community complaints through family planning counselors and compiling programs and activities according to community needs, but have not been able to realize all community aspirations due to limited funds, time and especially lack of Family Planning Extension; (c) responsibility, the organizational structure of the Office is able to support the implementation of the BKB-HI program, and employees from each line of organization carry out their respective duties and functions according to the rules and procedures as well as established work mechanisms; (d) accountability, accountability reports both financial reports and activity reports have been made and submitted to Murung Raya Regent. Service activities in the program are in accordance with the values and norms that develop in the community. But the hope of the community is that the intensification of program development in the field must be improved. (2) Factors that influence the performance of the Office are: (a) human resources and (b) facilities and infrastructure. The dominant factor that influences the performance of Dinas is human resources, namely the lack of family planning counselors.

Keywords: performance of institutions, early childhood development programs, integrative holistic.

Copyright @ 2019: This is an open-access article distributed under the terms of the Creative Commons Attribution license which permits unrestricted use, distribution, and reproduction in any medium for non-commercial use (NonCommercial, or CC-BY-NC) provided the original author and source are credited.

\section{INTRODUCTION}

Along with the decentralization of authority, several matters have led to the demands of the community towards the government to provide the best output to the community through overall performance and service. One of the mandatory functions not related to basic services delivered to the Regional Government is the affairs of population control and family planning which were previously fully managed by the BKKBN and BKKBN Representatives in the province. However, after being submitted, there was a tendency to decrease the commitment of the Regional Government to this program both in terms of budget allocation and advisory personnel in the field, namely Family Planning Extension. The government implements this law in fostering family resilience and welfare through improving the quality of children by giving birth to a program called Bina Keluarga Balita (BKB). 
The Indonesian government realizes that in an effort to create quality human resources with personality and abilities it cannot be done in an instant way, but must be formed and started from an early age, because in the entire life cycle of humans at an early age is a very important period in the process of formation the quality of a child who will be the next generation. At this age the process of brain and physical growth and the development of children's intelligence is very rapid, so it requires the fulfillment of overall needs both in terms of physical and health, education and stimulation, and love and protection from parents, closest families even from the surrounding environment, so that children has a foundation in ability and intelligence in thinking, acting and interacting in a social environment, acting in the face of problems and having a strong religious foundation.

The BKB program was first proclaimed by President Soeharto in 1981. BKB is an effort to increase the knowledge, skills and awareness of parents and other family members who have toddlers in fostering their children's growth through physical, motoric, intelligence, social, emotional and moral stimuli that take place in the process of interaction between parents and children under five. Toddler Family Development is an activity specifically managing the development of child development through correct parenting based on age groups, which is carried out by a number of cadres and at the community unit level [1].

The Head of BKKBN in 2009 has revitalized $\mathrm{BKB}$ to become BKB Holistic Integrative (BKB-HI) to fulfill services to early childhood as a whole and continuously. BKB-HI is BKB implemented in an integrated manner with POSYANDU and PAUD so that it can provide comprehensive and integrated services in fulfilling children's basic rights, namely to get adequate nutrition, basic health services in health facilities, stimulation and education and compassion. These three service programs already exist in the community but are still implemented partially and are not coordinated with each other, so they need to be integrated in order to jointly achieve the noble ideals of creating quality human resources.

As the decentralization of authority should have increased program implementation, it turned out that there was a tendency to decrease the commitment of the Regional Government to this program in terms of guidance, budget allocation, group operational support and welfare of cadres. However, there are still a number of regions that are still consistent and have high commitments in programs involving early childhood services including BKB-HI, one of which is the city of Surabaya. The City Government has 31 sub-districts and 162 villages with Integrative Holistic BKB groups totaling 850 with an average cadre of 6-8 people per group. This shows that the implementation of the BKB$\mathrm{HI}$ program in this region has high government support and community participation. Government support is indicated by the enactment of Surabaya Mayor Regulation number 20 of 2008 concerning General Guidelines for Integrated Early Childhood Education Post program. This regulation contains the Surabaya City government policy in the context of efficiency and effectiveness of implementation in the field, POSYANDU, BKB and PAUD activities carried out by integrating activities with the POS PAUD TERPADU name. So the three activity programs concerning efforts to fulfill children's basic rights carried out in an integrated manner both in planning, implementation and monitoring and evaluation with operational technicality were carried out through the Operational Working Group (POKJANAL) at the City, District and SubDistrict levels. This policy is quite effective because every line of government up to the RW level has clear duties and responsibilities in program mobilization and guidance.

The Murung Raya Regency Government through DP2KBP3A has conducted socialization and advocacy, cadre training and guidance for BKB-HI groups in all areas of Murung Raya Regency. However, the existence of the BKB-HI group for the Murung Raya Regency community is still not fully utilized, where the existence of the BKB-HI group is still minimal, from 124 villages/villages in 10 sub-districts there are only $32 \mathrm{BKB}-\mathrm{HI}$ groups formed, while based on the $\mathrm{BKB}$ group guidebook that the $\mathrm{BKB}$ program is implemented at the village/community unit level, so that every village in Murung Raya Regency should have a BKB Group.

Based on these data it can be concluded that the number of BKB groups in Murung Raya Regency does not meet the standards, namely one village has only one BKB group. The BKB groups that have also not all been integrated into the BKB-HI group outlined that the BKB group was revitalized to become BKB-HI, which was integrated with other early childhood services, namely POSYANDU and PAUD. This indicates a lack of cross-sectoral coordination, because the implementation of programs and activities in the effort to develop early childhood in Murung Raya Regency should not work individually, but is carried out in an integrated and holistic manner which is arranged through operational techniques that regulate crosssectoral collaboration and regulate the division of tasks and responsibility for mobilizing and training programs.

The implementation of the program in each group varies both in terms of organization, management personnel, implementation mechanisms and infrastructure that have an impact on the sustainability of this group in the midst of the community. There are several groups of BKB-HI that are carried out according to the $\mathrm{BKB}$ group guidebook guidelines, but the other groups are still limited, there is only group legality in the form of a decree from the Village Head/Village 
Head about group formation without the support of adequate infrastructure.

The lack of cadres is also one of the problems in implementing the BKB program. There are six age groups in one $\mathrm{BKB}$ group, namely the age group 0-1 years, 1-2 years, 2-3 years, 3-4 years, 4-5 years, 5-6 years. Each age group requires a minimum of two cadres so that one BKB group has at least 12 cadres, although basically each age group ideally needs three cadres, namely core cadres, picket cadres and auxiliary cadres, so ideally each group BKB-HI has 18 cadres. The relatively low capacity of cadre knowledge is also one of the obstacles in the implementation of activities, although many cadres have been trained but still have not mastered extension materials.

Based on the data in the field, it was found that 32 BKB groups in Murung Raya District had only 12 BKB groups or $37.5 \%$ of the total group that had cadres according to their needs, and trained cadres were 147 people or only $49.83 \%$ of the total BKB cadres in Kabupaten Murung Raya, and only 20 people were able to provide counseling or $13.6 \%$ of the total cadres who had been trained. The lack of cadres who are able to provide counseling is a challenge for DP2KBP3A Murung Raya Regency to continue to increase the capacity of knowledge and skills of cadres in providing counseling. The lack of cadres who were able to provide counseling did not totally obstruct the implementation of activities in the BKB group as long as the group had cadres who were able to provide counseling, but it would be a problem if BKB groups still did not have cadres who were able to provide counseling because extension activities could not be carried out properly.

There are still many BKB groups that are not active. This should be the task of the Family Planning Field Extension Officer in fostering and paying attention to groups that have been formed. Field Officers Family planning instructors are civil servants and/or non-civil servants who are in charge of implementing, managing and mobilizing communities in family planning programs at the village. One of the technical competencies of the Family Planning instructor is to initiate and facilitate the formation of BKB, Adolescent Family Development, Elderly Family Development, Youth Information and Counseling Center and Efforts to Increase Prosperous Family Income and carry out guidance every month to these groups, many Toddler Family Development groups are inactive. Based on the data found in the field, it is known that the BKB group in Murung Raya District has only 14 groups from the whole group or $43.75 \%$ who have active activities and $18 \mathrm{BKB}$ groups or $56.25 \%$ of the total non-active groups, this should be a concern Family Planning Extension Agency whose job is to provide guidance or assistance to BKB groups. Based on the description above, it is deemed necessary to conduct research on the Performance of DP2KBP3A in Murung Raya Regency and the factors that influence it in the BKB-HI program in Murung Raya Regency.

\section{METHODS}

This type of research is qualitative descriptive with case study design. The focus of the research is on several things, namely the performance of the DP2KBP3A in BKB-HI in Murung Raya and the influencing factors such as productivity, responsiveness, responsibility, and accountability. Data collection is done by collecting two types of data, namely primary data by conducting interviews with parties directly related to the BKB-HI program in the field and secondary data, namely written documents. Technical data analysis in this study uses analytical techniques according to Miles and Huberman [2], where there are three qualitative data analysis techniques, namely data reduction, data presentation, and conclusion drawing. The research location is located in Murung Raya Regency and the unit which is the subject of the research is DP2KBP3A Murung Raya Regency.

\section{RESULTS \\ Performance of the DP2KBP3A in the BKB-HI program}

Services for early childhood in Murung Raya Regency have been carried out various programs, namely Integrated Health Service Post (POSYANDU), Early Childhood Education (PAUD), Child Care Center (TPA), Play Group (KB) and BKB-HI. This Integrative Holistic concept is carried out because in the community environment various activities have been carried out that provide basic services for children, but the implementation of services is still sectoral, partial and not yet well integrated. The integration of services provided is expected to work together in order to meet the basic needs of children.

The condition of society which has begun to change and is full of dynamics requires government organizations to always make various efforts to improve performance. Likewise, the Office of Population Control for Family Planning for Women's Empowerment and Child Protection of Murung Raya Regency, as a starting point for improving performance, it is necessary to measure the performance carried out in order to determine the extent of the achievement of the performance of this service, especially in the BKB-HI program.

So far, DP2KBP3A of Murung Raya Regency's performance measurement tends to only pay attention to financial realization as outlined in the Government Institution Performance Report (LAKIP), where a program and activity will be declared successful in implementing the program if the financial realization has reached $100 \%$ without paying close attention to the quality of program implementation in the field. Measuring the performance of government 
organizations is still insufficient if it only considers aspects of budget realization, but it must be assessed to cover various aspects concerning productivity, accountability and alignment of the program with the needs of the community. As stated in Chapter II that in measuring the performance of the Family Planning Population Control Office for Women's Empowerment and Child Protection in Murung Raya Regency in the Integrative Holistic Family Development program the authors used four performance measurement indicators from the five indicators proposed by Dwiyanto [3], namely: 1) productivity, 2 ) responsiveness, 3) responsibility, and 4) accountability.

\section{Productivity}

Productivity here not only measures efficiency, but also service effectiveness. Measurement of DP2KBP3A productivity in Murung Raya Regency in implementing the BKB-HI program refers to the achievement of targets that have been determined in the implementation of the function as operational responsibility and the suitability of the program with strategies that refer to the vision and mission. Based on the results of interviews with the Head of DP2KBP3A, Murung Raya Regency, it can be drawn that the targets have not yet set targets as a reference for evaluating agency performance in terms of productivity. This relates to the availability of funds for group development to implement the BKB-HI program in the community. Meanwhile, in terms of the programs that has been prepared in accordance with the strategy that becomes the elaboration of the vision and mission of DP2KBP3A Murung Raya Regency by increasing the number of cadres and prioritizing increasing the competency of extension workers in the field.

\section{Responsiveness}

In short, responsiveness shows the harmony between programs and service activities with the needs and aspirations of the community. DP2KBP3A Murung Raya's responsiveness refers to the Agency's ability to recognize the needs of the community and develop public service programs in accordance with the needs and aspirations of the community. Based on the results of the interview, the informants' information about responsiveness can be drawn in outline, namely DP2KBP3A Murung Raya, paying attention to proposals, aspirations or complaints from the community. These proposals were accepted by the instructors and cadres in the field and submitted to the leadership to study the urgency, but when it came to other related agencies, it could not be accommodated. DP2KBP3A Murung Raya has not provided a complaint facility in the form of a complaints box, because the community complaints facility regarding the implementation of the BKB-HI program so that the process of delivering aspirations is done directly (verbally) through family planning counselors who work in each village, this method is considered more effective so that the existing complaints can be immediately served or handled by the field concerned. The organization follows up on proposals and aspirations from the community by arranging programs and activities according to the needs of the community, but the realization of the aspirations of the community is not yet fully implemented due to obstacles in the form of limited funds, time and human resources.

\section{Responsibility}

The DP2KBP3A Murung Raya responsibility refers to the suitability of the implementation of activities with administrative principles or applicable regulations and procedures. Based on the results of the interview, the informants' information about responsibility can be concluded that the organizational structure formed has been able to support the implementation of the BKB-HI program, the duties and functions of each head of the Division, Section Chief and Family Planning Instructor. This indicates that there is no overlap in the respective main duties and functions. The only obstacle lies in the absence of technical guidelines governing the implementation of activities in the field both in terms of organizing, management personnel, implementation mechanisms and infrastructure. This Technical Directive is needed as a reference in the implementation of activities both in terms of bookkeeping and reporting administration, activity implementation mechanism, BKB-HI organizational structure, infrastructure facilities as well as the distribution of authority and obligations between DP2KBP3A Murung Raya Regency with the district and village governments.

\section{Accountability}

Accountability of DP2KBP3A Murung Raya in the BKB-HI program refers to the accountability report provided both financial reports and activity reports. Based on the results of the interview it can be concluded that the financial statements and activity reports have been made and submitted as a form of accountability to the Regent as the leader in Murung Raya Regency. The Office's activities in the BKB-HI program are considered true and in accordance with the values and norms that develop in society.

Based on the results of the FGD conducted by researchers at the BKB-HI "Tunas Makarti" Trans Bahitom in Murung District by inviting 5 members and 3 cadres to discuss the responsiveness and accountability of DP2KBP3A. According to the cadres they have carried out their respective duties and obligations so that the community response to this program is quite good. The BKB-HI program is considered good by the cadres and the community, but the instructor also complained that there must be guidance and guidance for them to improve competence and the program can continue. Unlike the case with the FGD results in Puruk Cahu, inviting cadres and Members of the BKB-HI group "Anyelir 1" to discuss the same problem, with the results of cadres who have 
been trained are still having difficulties in carrying out their duties such as difficulties in filling KKA so there is need for further guidance.

\section{Obstacles of DP2KBP3A in the BKB-HI program}

From the research results it is known that there are several obstacles faced by Murung Raya Regency's DP2KBP3A in the BKB-HI program, which are as follows:

1. The lack of staff supporting the implementation of the BKB program when compared to the number of villages that must be fostered, namely 25 people handling 115 villages and 9 sub-unit villages, so that the role of field officers cannot be carried out optimally.

2. There are no technical guidelines for the implementation of activities in the field specifically issued by DP2KBP3A Murung Raya Regency, so the implementation of activities in each group both in terms of organizing, management personnel and service mechanisms are still different.

3. There is no regulation yet at the same level as a Regent Regulation that regulates cross-sectoral cooperation in the management of Early Childhood Development in Murung Raya Regency, so that the relevant agencies, elements of village and subdistrict leaders do not have the same view in implementing the program.

4. There is not yet a budget available for the development of groups that implement the BKB-HI program in Murung Raya's DP2KBP3A, so that it experiences obstacles in determining the target for the formation of the BKB-HI group that must be achieved.

5. Lack of facilities and infrastructure including operational funds for family planning counselors to carry out training in each village.

6. There are still Family Planning Instructors who have not yet mastered the knowledge and skills regarding the management of the BKB-HI program, so that it has an influence on program development in villages and villages.

\section{DISCUSSION}

\section{DP2KBP3A Performance Assessment in the BKB-HI} program in Murung Raya

\section{Productivity}

DP2KBP3A productivity in terms of the efficiency of the use of funds provided for the implementation of programs and activities that have been budgeted especially in 2017 namely BKB-HI Cadre Training activities with a target of 40 participants and Smart Cadre orientation activities with a target of 20 people have been carried out according to the target set. In terms of effectiveness, it is the achievement of objectives precisely. Effectiveness can also be interpreted as a measurement of success in achieving the goals set. The success of the implementation of the activity with the target participants according to the plan according to the author has not been able to achieve effectiveness because it has not been able to make an impact in accordance with the expected goals of creating cadres who are able to provide information about nurturing and fostering growth and development of toddlers. This is based on data from Murung Raya Regency BKB-HI Cadres who are able to provide counseling to only $13.6 \%$ of the total cadres who have been trained.

Likewise, in the guidance of the BKB-HI group, the Agency has not yet set clear and targeted targets for the implementation of the BKB-HI program each year in terms of the quantity of groups that must be formed and fostered in each district, as well as the target of improving facilities and infrastructure that must be met. All of that has not been stated in the form of a written target plan, even though it needs to be socialized to internal and external parties such as district chief, village chief, the chairperson of the district and village PKK mobilization team and related cross-sectoral agencies. This causes difficulties in evaluating the performance results of these services from productivity indicators. The undetermined target also results in the non-maximum number of BKB-HI groups in Murung Raya Regency and its facilities and infrastructure. The programs and activities related to the BKB-HI that have been prepared are in accordance with strategies that refer to the Office's vision and mission.

\section{Responsiveness}

In terms of responsiveness, it can be analyzed that the Office follows up on proposals and aspirations or complaints from the community by accommodating and absorbing community complaints through family planning instructors who work in each village and compile programs and activities according to community needs, but the realization of community aspirations is still not fully implemented because there are obstacles in the form of limited funds, time and especially human resources that support the implementation of the Toddler Family Development Program, namely the Section Head of the Toddler, Children and Elderly Resilience Section whose main tasks and functions are to handle the BKB-HI program and have not been filled and the Family Planning Instructors being a milestone for program coaching in the field is still very minimal when compared to the number of villages that must be fostered, so that the role of field officers cannot be carried out optimally.

\section{Responsibility}

In terms of responsibility, it can be analyzed that the implementation of Murung Raya's DP2KBP3A activities is in accordance with administrative principles or applicable regulations and procedures. The organizational structure formed has been able to support the implementation of the BKB-HI program, the duties and functions of each head of Division, Section Head and Family Planning Instructor. Employee work 
procedures and mechanisms in the BKB-HI program can work well. Employees from each line of the organization carry out their duties and functions according to the rules and procedures of the work mechanism that have been set. Nevertheless activities that support the BKB-HI program as well as coaching in the field have not been able to be carried out optimally due to human resource constraints. In addition, there is no technical guidance needed as a reference in the implementation of activities both in terms of bookkeeping and reporting administration, activity implementation mechanism, BKB-HI organizational structure, infrastructure facilities as well as distribution of authority and obligations between DP2KBP3A Murung Raya Regency with the district and village governments.

\section{Accountability}

In terms of accountability DP2KBP3A Murung Raya Regency in the BKB-HI program can be concluded that the accountability reports provided, both financial reports and activity reports have been made and submitted as a form of accountability to the Regent as the leader in Murung Raya Regency. The Office's activities in the BKB-HI program did not receive complaints from the community because they were considered to be in accordance with the values and norms developed in the community. However, the community's expectation is that the intensification of program development in the field must be increased, so that the real benefits of this program can be felt by the community in the context of optimizing the development of child development towards a quality generation.

\section{Factors affecting DP2KBP3A performance in the BKB-HI program in Murung Raya}

From the results of the study it can be concluded that there are several factors that affect the performance of Murung Raya's DP2KBP3A in the BKB-HI program in Murung Raya Regency, as follows:

\section{Organization goals}

According Atmosoeprapto organizational goals are what they want to achieve and what they want to produce [4]. In this study, it was found that DP2KBP3A Murung Raya Regency in the management of the BKBHI program did not make a written target, which contained the number of groups that had to be formed and fostered annually, the improvement of facilities and infrastructure that had to be fulfilled including increasing the quantity and quality of cadres managing the BKB-HI group. This causes the quantity of the BKB-HI group to be minimal and the quantity and quality still low, thus affecting the service performance in terms of productivity.

\section{Organizational structure}

According to Soesilo organizational structure is defined as internal relations relating to the functions that carry out organizational activities [4]. From the results of the study it can be concluded that the organizational structure of DP2KBP3A Murung Raya Regency has been prepared to support the implementation of Agency programs including the BKB-HI program. Employee work procedures and mechanisms have been clearly described so that they can run well; this has a positive effect on Agency performance in terms of responsibility.

\section{The quality of inputs or materials used by the organization}

According to Ruky one of the factors influencing organizational performance is the quality of inputs or materials used by organizations [4]. Included in the input of the BKB-HI program in Murung Raya Regency consists of human resources and capital or infrastructure used including the budget provided for program implementation.

\section{Human resources}

According Atmosoeprapto [5] human resources that affect performance is the quality and management of organizational members as the driving force of the organization as a whole, according to Zauhar [6], human resources that are related to the quality of employees to work and work optimally. The quality of human resources in this case is employees of the DP2KBP3A of Murung Raya Regency includes the ability to think, conduct analysis in decision making and the skills to do daily tasks, especially the Family Planning Instructors who carry out the Family Development Program assistance Integrative Holistic Toddler in the field. This capability is very necessary in the implementation of tasks that are in direct contact with the community, in order to support the achievement of the Agency's performance in terms of responsiveness.

There are still Family Planning Instructors who have not yet mastered the knowledge and skills regarding the management of the BKB-HI program, so that it has an influence on program development in villages and villages. The lack of staff supporting the implementation of the BKB-HI program, both structural staff working in the office as well as Family Planning Field Instructors who are tasked with implementing, managing and mobilizing the community in this program at the village and kelurahan level, greatly affects the Agency's performance, because the workload is too heavy with a range of work area that is too broad, where there are only 25 people handling 115 villages and 9 villages, so that program development in villages and villages cannot be carried out optimally according to established standards. In this study it was found that the lack of family planning counselors was one of the factors that most influenced the Agency's performance.

\section{Asset or infrastructure used}

Asset or infrastructure used in the BKB-HI activities in Murung Raya Regency includes the budget 
and work equipment provided for the implementation of the program. Lack of facilities and infrastructure including operational funds for family planning counselors to carry out training in each village has an effect on program development. The unavailability of a budget for group coaching that implements the BKB-HI program in Murung Raya's DP2KBP3A also becomes an obstacle to the Agency's performance because it experiences obstacles in determining the group formation target that must be achieved.

\section{CONCLUSION}

From the results of research conducted on the performance of Murung Raya DP2KBP3A in the BKB$\mathrm{HI}$ program by using four assessment indicators namely productivity, responsiveness, responsibility and accountability, it can be concluded that:

\section{Productivity}

In terms of effectiveness, it is considered not yet capable because it has not been able to make an impact in accordance with the expected goals of creating cadres who are able to provide information about nurturing and fostering growth and development of toddlers. The formation of the BKB-HI group has not yet set clear and targeted targets as outlined in the form of a written target plan, resulting in the non-maximum number of BKB-HI groups in Murung Raya Regency and its facilities and infrastructure.

\section{Responsiveness}

Proposals and aspirations or complaints from the community have been followed up by accommodating and absorbing community complaints through family planning instructors who work in each village and arrange programs and activities according to community needs, but not all community aspirations can be implemented due to obstacles in the form of limited funds, time and especially resources people who support the implementation of the Toddler Family Development program, namely the lack of family planning counselors.

\section{Responsibility}

In terms of responsibility it can be explained that the organizational structure of DP2KBP3A Murung Raya Regency is able to support the implementation of the BKB-HI program, and employees from each line of organization carry out their respective duties and functions according to the rules and procedures and work mechanisms that have been determined. However, activities that support this program as well as coaching in the field still cannot be carried out optimally because of the shortage of family planning counselors as program supervisors in the field.

\section{Accountability}

In terms of accountability, it can be concluded that the accountability reports provided, both financial reports and activity reports have been made and submitted as a form of accountability to the Regent as the leader in Murung Raya Regency. The Office's activities in the BKB-HI program did not receive complaints from the community because they were considered to be in accordance with the values and norms developed in the community. But the hope of the community is that the intensification of program coaching in the field must be increased.

\section{RECOMMENDATIONS}

Based on the results of the following research some recommendations are recommended to improve the performance of Murung Raya Regency DP2KBP3A as follows:

- DP2KBP3A Murung Raya should make clear and targeted targets on the formation and formation of BKB-HI groups every year both in terms of the number of groups that must be formed per district and improvement of facilities and infrastructure that must be met for the implementation of the BKB-HI program and set forth in written target plan form.

- DP2KBP3A Murung Raya should make technical guidelines for the implementation of the BKB-HI program in the field so that they become a reference for group managers in carrying out activities, so that the implementation of activities can be carried out according to the rules.

- DP2KBP3A Murung Raya is expected to carry out advocacy and socialization of the BKB-HI program in order to increase cooperation and cross-sectoral support, especially village or district government in providing coaching budgets as operational costs for implementing activities at the village or sub-unit district level.

- For the sake of improving performance in the BKB-HI program in Murung Raya, it is hoped that the Regional Government can fill vacant positions for the Section Head of Toddler, Child and Elderly Resilience Section and increase the number of family planning counselors as program supervisors in the field.

- In order that cross-sectoral cooperation can be carried out with an orderly arrangement in the implementation of the program, it is hoped that the Regional Government can form a Regulatory Regulations governing cross-sectoral cooperation in the management of Early Childhood Development in Murung Raya.

\section{REFERENCES}

1. BKKBN. (2013). Buku Panduan Pelaksanaan Kegiatan Bina Keluarga Balita (BKB) Yang Terintegrasi Dalam Rangka Penyelenggaraan Pengembangan Anak USIA Dini Holistik Integratif. BKKBN: Jakarta.

2. Miles, Mattew B., \& Amichael, H. (2007). Analisis Data Kualitatif Buku Sumber tentang Metode- 
Metode Baru. Terjemahan Tjetjep Rohendi Rohisi. Jakarta: Universitas Indonesia.

3. Dwiyanto, Agus. (2006). Reformasi Birokrasi Publik di Indonesia. Yogyakarta: Gadjah Mada University Press.

4. Tangkilisan, Hessel, N. S. (2005). Manajemen Publik. Jakarta: PT Gramedia Widiasarana.
5. Atmosoeprapto, K. (2005). Produktivitas Aktualisasi Budaya Perusahaan. Elex Media Komputindo: Jakarta.

6. Zauhar, S. (2005). Pengaruh Pengembangan Sumber Daya Aparatur terhadap Kinerja Pelayanan Publik di Kota Malang. Dissertation. PPs Unpad: Bandung. 